Reprinted from the "Proceedings of the Indian Academy of Sciehces,"Vol. LVII, 1963

\title{
GROSS MORPHOLOGY AND HISTOLOGY OF NEPHRIDIA IN FOUR SPECIES OF POLYCHAETES
}

BY

B. KRISHNAMOORTHI 


\title{
GROSS MORPHOLOGY AND HISTOLOGY OF NEPHRIDIA IN FOUR SPECIES OF POLYCHAETES
}

\author{
BY B. KRISHNAMOORTHI \\ (Zoological Research Laboratory, University of Madras, Madras-5) \\ Received November 2, 1962 \\ (Communicated by Dr. S. Krishnaswamy, F.A.Sc.)
}

\section{INTRODUCTION}

IN a recent paper (Krishnamoorthi, 1962) it was shown that the four polychaetes studied, viz., Glycera embranchiata Ranganathan, Onuphis erPmita - Loimia medusa Savigny and Clymene insecta Ehlers, exhibited differences in their capacities for volume regulation when subjected to stresses of anisotonic media. Jurgens (1935), Beadle (1937) and Ewer and Ewer (1943) have brought evidence of the relative importance of excretory organs in the volume regulation of the polychaetes they had studied. It is known that the excretory organs exhibit differences in size and structure in nearly related species occurring in marine and brackish-water habitats as has been shown in fishes (Marshall and Smith, 1930; Nash, 1931); in Turbellaria (Westblad, 1922); in Crustacea (Marchal, 1892; Schlieper and Herrmann, 1930; Schwabe, 1933; Peters, 1935) and in Polychaetes (Krishnan, 1952). It appeared, therefore, that a knowledge of the anatomy and histology of the Nephridia of the above four species would throw some light to account for the differences in their abilities for volume regulation and their distribution in a brackish-water environment.

\section{Material and Methods}

The polychaetes studied were obtained from the brackish-water regions of Adyar, Madras, as well as the shores of Madras. While C. insecta and L. medusa were taken from the brackish-waters, G. embranchiata and O. eremita were taken from the intertidal zones of the Madras coast. The worms were collected and brought to the laboratory in earthen pots immediately. They were narcotised to ensure an extended condition with Chloral Hydrate and Menthol before fixing them. Gradual addition of $30 \%$ alcohol was also found suitable for narcotisation. Bouin's fluid, Duboscq Bouin, Zenker's fluid and Susa were found most suitable for fixation. Sections were cut 
on a Spencer's Rotary Microtome to 4 to $7 \mu$ thickness and were stained with Haemotoxylin or Borax Carmine which gave excellent results. All diagrams were made with the aid of a Camera Lucida. An ordinary micrometer was used for measurements recorded, keeping the magnification $5 \times 8$ constant.

\section{III. (A) NePhridia IN O. erPmita}

(i) Previous work

Ehlers (1864) was the first to study the nephridia in Eunicidae. But it was Goodrich $(1900,1945)$ who gave a detailed account of the nephridia of Eunicidae. Fage (1906) added to this knowledge describing the nephridia in some more genera. Aiyar (1933) confirmed the mixed nature of the nephridium in Marphysa gravelyi Southern, a common Eunicid of Madras.

\section{(ii) Structure}

The nephridia in O. eremita, as in all Eunicidae, occur a pair per segment except in the few anterior and posterior segments where there are none at all. It is trumpet shaped with a wide nephrostome and a tapering nephridial canal which becomes the narrowest before opening out by the nephridiopore (Fig. 1). Each nephridium occupies a position lateral to the longitudinal muscle and ventral to the pigment gland. It starts from the outer edge of the ventral longitudinal muscle and following its contour, runs outwards. At the level of the circular layer of muscles, it pierces through it as well as the epidermis to open by the nephridiopore at the base of the neuropodium

The broad nephrostome, with the anterior lip very close to the intersegmental septum and the posterior lip freely hanging into the segment, is cup-shaped (Fig. 2). The concavity of the cup is turned towards the coelomic space. It gradually narrows down till it becomes continuous with the nephridial canal. The walls of the nephrostome are made up of a single layer of similar celis $10 \mu$ in length, with uniformly granulated and transparent cytoplasm. But the cell limits are not clear. Each cell bears a number of cilia packed together and overhanging the lumen of the nephrostome. Nuclei are excentric being towards the proximal end (Fig. 3). The nephrostome, except where it opens into the coelomic cavity, is surrounded immediately by the coelomic epithelium and an outer much vacuolated connective tissue.

The commencement of the nephridial canal from the narrower end of the nephrostome is not well demarkated. Cross-sections and longitudinal sections (Figs. 4 and 5) reveal that the walls of the nephridial canal are made up of a single layer of cubical cells $2 \mu$ in length with not very distinct cell 
limits. In addition to small granules, bright refringent bodies and vacuoles are present in the cells. The lumen of the canal is of uniform size all through its entire length except at the region of the nehpridiopore where it becomes constricted before opening to the outside. The nephridial canal, as the nephrostome, is surrounded immediately by the coelomic epithelium and an outer much vacuolated connective tissue.

At the time of maturity the nephridia take on the function of the genital ducts. In a gravid worm the nephrostome becomes much enlarged (Fig. 6) so also the nephridial canal to facilitate the passage of the genital products. Such a condition could be noticed only in the nephridia of the posterior segments and perhaps only the posterior segments are concerned in this process, while the nephridia of the anterior segments continue their excretory function. Similar observations in Eunice sp. have been made by Goodrich (1900).

\section{III. (B) NePhridia IN Loimia medusa SAVIGNY}

(i) Previous work

We owe our knowledge of nephridia in Terebellids to Milne Edwards (1838), Keferstein (1862), Cunningham (1887 $a$ and $b$ ), Schneider (1899), Cosmovice (1880) and Hessle (1917).

\section{(ii) Structure}

In L. medusa there are three pairs of nephridia-one in the cehpalic region consisting of the first three segments and the other two in the trunk region made up of the rest of the segments. The first pair is located in the III segment while the second and the third pairs are disposed inter segmentally between the VI-VII segments and VII-VIII segments respectively. A diaphragm demarkates, at their region of the IV-V segments, the cephalic and the trunk regions (Fig. 7). This division of the body and the arrangement of the nephridia in $L$. medusa recalls the description of nephridia in Pectinaria belgica (Cunningham, 1887) which, however, has one more pair in the trunk region.

(a) Nephridia of the Cephalic Region--Commencing from the nephrostome which is situated near the gut, the first part of the nephridial canal is very narrow and runs dorsalwards to open into a wider part which is longer and runs straight outwards, after an initial twist, to the parapodia of the segment II, to open out by the nephridiopore on an elevated papilla (Figs. 8 and 9).

The nephrostome is spherical and globular in shape with a wide slit in the middle by which it opens into the coelomic cavity near the gut (Fig. 10). 
The wall of the nephrostome is formed of a single layer of cells, 6 to $7 \mu$ long with indistinct cell boundaries. All the cells of the inner wall of the nephrostome carry a number of cilia measuring $15 \mu$ long directed towards the nephridial canal. The lumen of the nephrostome is broad and does not decrease in size. Further there is no trace of either coelomic epithelium or connective tissue surrounding the nephrostome. Unlike in Lanice conchilega and Arenicola (Cunningham, 1887) the nephrostome is not provided with digitate processes.

In a nephridium of $1140 \mu$ long, the first and the narrower part of the nephridial canal, $20 \mu$ long, commences its course a little excentrically from the nephrostome (Fig. 10). Its wall is one cell thick (Fig. 11). The cells have indistinct boundaries but have prominent deeply staining nuclei. The cells bear cilia $8-10 \mu$ long. The cytoplasm is uniformly granular. Vacuoles occur but rarely. Cellular inclusions like the refringent bodies are absent. It opens into the wider part of the nephridial canal.

The wider part measuring $1120 \beta$ in length is also one cell thick (Fig. 12). The cells are $8 \mu$ long and have better differentiated boundaries and centrally placed prominent nucleus. They bear longer cilia measuring about $20 \mu$ long.

The cytoplasm is more granular towards the periphery of the cells and contains large refringent bodies. Hence this part of the nephridial canal is darker in colour than the rest. As Schneider (1899) describing such a condition in the nephridial canal in Pectinaria hyperborae, Terebellides stromii, Polymnia nebulosa and Polymnia nidensis considers the cells engaged in active removal of excretory products, this dark-coloured part of the nephridial canal in L. medusa may also be capable of a similar function.

(b) Nephridia of the trunk region.--These nephridia (Fig. 13) differ from the cephalic nephridia in the absence of the narrow region of the nephridial canal so that the lumen is wide throughout-fit for the passage of the gonadial cells. Nevertheless, there is considerable similarity in the nephrostome being spherical and globular; the nephridial canal opening out on an elevated papilla; the cells of the wall of the canal having refringent bodies. It is probable that they discharge excretory function with equal efficiency. There is no common chamber or tube connecting all the nephridia as in Peetinaria belgica (Cunningham, 1887). 


\section{III. (C) NEPHRIDIA IN Glycera embranchiata RANGANATHAN}

\section{(i) Previous work}

Nephridia in G. unicornis, G. siphonostoma and G. convolutus have been described (Goodrich, 1898). Fage (1906) has described the nephridia in G. alba and G. tessellata. Ranganathan (1942) created the species and gave a brief description of the nephridium.

\section{(ii) Structure}

The nephridia in this form, as in all other Glycerids, are of the protonephromixial type (Fig. 14) and occur in all segments excepting a few anterior and posterior ones. Each nephridium consists of two parts, the protonephridium and the coelomoduct. The protonephridium is a large sac-like swelling provided with characteristic solenocytes; and leads into a narrow duct opening to the exterior. The coelomoduct is modified to form a funnelshaped ciliated organ leading into a phagocytal sac (Goodrich, 1898). Composed of these parts each nephridium is intersegmental in position, the major portion being in front of the septum and the post-septal part being only of the duct, opening at the base of the parapodium.

The protonephridium is without an opening into the coelomic cavity and consists of a sac-like nephridial swelling and the nephridial duct. The wall of the nephridial swelling is of a single layer of syncytial cells of granular character, enclosing a large cavity into which the solenocytes open. Each solenocyte is a spherical mass of protoplasm which narrows into the proximal transparent part attached to the nephridial swelling (Fig. 15). This narrow stalk-like portion is hollowed into a tube which dilates into a large intercellular cavity within the lumen of the cell (Fig. 16). The nucleus is situated at the spherical end.

The nephridial duct is the narrow outward extension of this sac extending from the level of the septum to the ventral region of the parapodia where it opens to the exterior by a narrow circular nephridiopore. The walls of the duct, as in the nephridial swelling, are syncytial with scattered nuclei and uniformly granular cytoplasm (Fig. 17). The lumen of the duct is continuous with the cavity of the nephridial swelling and contain excretory products.

The presence of the excretory products in the lumen of the nephridial duct suggests their passage into it by the action of the solenocytes which probably absorb them from the coelomic fluid. Similar observations have been made by Goodrich (1898) in Glycera siphonostoma and by Fage (1906) in Glycera tessellata. 
The coelomoduct part of the nephridium is an extremely short funnelshaped ciliated organ dilating into the phagocytal sac. The opening at the free end of the funnel-like ciliated organ, is a wide transverse slit bounded by thick upper and lower lips. The upper lip has a transverse groove on its dorsal surface running parallel to the edge. The cavity within the ciliated organ is lined by numerous cilia which by their movements drive the excretory products along with the coelomic fluid into the phagocytal sac. The lips consists of cuboid cells $8 \mu$ long.

The phagocytal sac is longer and wider than the ciliated organ. It is a thick-walled sac. Communicating in front with the ciliated organ, it is continued behind into a short blind tube which ends posteriorly to the septum. The cells forming the wall are cuboid and $12 \mu$ long, whereas those of the blind tube are much smaller. In Glycera siphonostoma and Glycera unicornis (Goodrich, 1898) there are two blind caecae which increase the surface of this phagocytal sac. The large cuboid cells of this sac are phagocytal in character. The excretory bodies wafted into the sac along with the coelomic fluid are ingested by the cells of the sac. As there is no external outlet, it is not clear how these bodies are disposed of. Goodrich's (1945) suggestion that these bodies may be later digested by the cells and the waste matter may be passed through the walls of the protonephridial duct and thus reach the outside, seems likely.

\section{III. (D) NEPHRIDIA IN Clymene insecta EHLERS}

\section{(i) Structure}

There are four pairs of nephridia occurring in segments VI, VII, VIII and IX and each nephridium is of the mixonephridial type and extends the whole length of the segment. It is looped and consists of a nephrostome and two limbs of the nephridial canal, an outer limb running close to the body wall and an inner limb away from it. The inner limb opens out by the nephridiopore at a distance approximately $1 / 3$ the length of the segment from the septum (Fig. 18). Invariably the third pair of nephridia is the largest in size.

The nephrostome, which is funnel-shaped, has a transverse and elliptical opening, the axis being $96 \mu$ long and consists of two lips. The upper lip of the opening is closely attached to the septum while the lower lip hangs freely in the coelomic cavity. Its walls are made up of a single layer of uniform cubical cells. Each cell, $8 \mu$ long, has a spherical centrally placed nucleus. The surrounding cytoplasm is granular, granulation being more at the proximal end. Cellular inclusion like the refringent bodies are absent (Fig. 19). 
Arising from each cell and hanging into the lumen are a number of long cilia measuring about $15 \mu$. The lumen is of uniform size throughout the length of the nephrostome and is full of waste matter probably of a nitrogenous nature. The outer side of the nephrostome is covered by an extension of the coelomic epithelium which, however, stops short of the lips. The nuclei are uniformly distributed in this layer. Surrounding it is the loose and much vacuolated connective tissue which serves to fix the nephrostome to the wall of the coelomic cavity where the nuclei are not distributed uniformly.

Though the opening is larger and elliptical in form the two lips appear always apart. The inflow of the coelomic fluid is thus uninterrupted.

The nephridial canal is a narrow tube commencing from the narrow end of the funnel-shaped nephrostome. It is $1.2 \mathrm{~mm}$. long with a cnstriction beyond $1.1 \mathrm{~mm}$., and it bends about it. The walls of both the limbs are made up of a single layer of uniform cubical cells each having a size of $10 \mu$ (Fig. 20). The outer longer limb is darker in colour, has granular cytoplasm and contains refringent bodies (Fig. 21). The cells of the nephridial canal contain vacuoles, also indicating water elimination. Arising from each cell of both the limbs are number of hair-like cilia which in a living worm can be seen actively beating away from the nephrostome. They hang freely into the lumen. Surrounding the limbs and very close to them lies the coelomic epithelium with its uniformly distributed nuclei. Outside the coelomic epithalium and surrounding the limbs is the connective tissue with its scattered nuclei.

\section{BloOd Supply to NePHRIDIA}

The blood supply, the nephridia of Polychaetes receive, deserves attention because the amount of blood supply is not only a measure of the degree of metabolic activity but also throws light on the nature of their activity. In the Eunicid, O. erfmita, the nephridia receive blood by a branch of the ventral blood vessel as in Eunice sp. (Goodrich, 1900). The main branch of the ventral vessel supplies the parapodia as well as the branchia and before it proceeds to the parapodia and the branchiae proper, it gives a subsidiary branch to the nephridium which breaks into capillaries on the nephridial body and is brought back by the general circulation of the blood to the epidermis. Several of the capillaries end blind within the nephridia as in Marphysa sanguinea, also an Eunicid (Fuchs, 1906). The nephridia of L. medusa are supplied by a vessel directly from the ventral blood vessel as in Terebella conchilega (Cunningham, 1887), and contain blind-ending 
capillaries. As far as can be studied from sections the blood supply in $C$. insecta and $G$. embranchiata also is similar to the other forms studied.

TABLE A

Blood supply in the four species of Polychaetes studied

\begin{tabular}{|c|c|c|c|c|c|c|c|c|}
\hline \multirow{2}{*}{ Genera } & \multicolumn{8}{|c|}{ Number of blind-ending capillaries in the worms } \\
\hline & & $1 \mathrm{st}$ & $2 \mathrm{nd}$ & $3 r d$ & 4 th & 5 th & 6th & Average \\
\hline Glycera & $\cdots$ & 12 & 12 & 11 & 12 & 12 & 12 & $11 \cdot 83$ \\
\hline Onuphis & .. & 16 & 16 & 16 & 15 & 16 & 5 & $15 \cdot 66$ \\
\hline Loimia & $\cdots$ & 16 & 17 & 16 & 16 & 17 & 17 & $16 \cdot 50$ \\
\hline Clymene & . & 23 & 23 & 23 & 22 & 22 & 23 & $22 \cdot 66$ \\
\hline
\end{tabular}

However, it is evident (Table A) that the number of blind-ending capillaries vary in the different forms. If the number of such capillaries (which are obviously of importance because the blood they bring is undoubtedly irrigating the nephridial tissue) be counted and used as an index of the degree of vascularisation, we will have a basis for the comparison of different types of nephridia, and their grade of renal activity, as has been suggested by Jaquet (1885), Meyer (1888), Cosmovice (1880) and Ewer (1941) for the polychaetes studied.

\section{EXTENT OF THE EXCRETORY SURFACE OF THE NePHRIDIUM Relative to THE Size OF THE WORM}

Evidence from the study of the structure of the nephridia of different polychaetes go to show that since the nephrostome does not take part in the actual process of excretion, except to aid in the collection of nitrogenous waste matter, the nephridial canal, lying between the nephrostome and the external opening, must be responsible for the different renal processes. The length of the canal, implying the greater number of cells, may therefore be an index of the excretory capacity of the nephridium of any animal. In order to arrive at some value likely to be constant for different genera of polychaetes, the ratio between the length of the nephridial canal to the length of the worm was determined in the different forms studied and tabulated (Tables I, II, and III). Such a ratio was not derivable for Glycera embranchiata because 
Gross Morphology and Histology of Nephridia in Speeies of Polychaetes 203

the cells of the wall of the nephridial canal are of syncytial nature and measurements are not likely to be accurate. It is evident from the tables that in $C$. insecta the ratio is higher than in either O. erimita or L. medusa. Such a grading on the basis of the excretory capacity tallies with their powers of tolerating dilution of the media and migration up the river (Krishnamoorthi, 1962). Whereas $C$. insecta is a pronouncedly euryhaline form, both $O$. ermita and $L$. medusa are stenohaline. Such a correlation between kidney structure and the habitat has been studied in Crustacea (Grobben, 1881; Schwabe, 1933; Panikkar, 1941); in fishes (Marshall and Smith, 1930) and in Polychaetes (Krishnan, 1952).

\section{TABLE 1}

Onuphis erfmita--Extent of the excretory surface relative to the length of the worm

\begin{tabular}{|c|c|c|c|c|c|c|}
\hline No. & $\begin{array}{l}\text { Length } \\
\text { of the } \\
\text { worm } \\
\mathrm{mm} \text {. }\end{array}$ & $\begin{array}{c}\text { No. of } \\
\text { seg- } \\
\text { ments }\end{array}$ & $\begin{array}{l}\text { Length of } \\
\text { each cell } \\
\text { of the } \\
\text { nephridial } \\
\text { canal } \\
\mu\end{array}$ & $\begin{array}{l}\text { No. of } \\
\text { such } \\
\text { cells }\end{array}$ & $\begin{array}{l}\text { Length } \\
\text { of the } \\
\text { nephridial } \\
\text { canal } \\
\mu\end{array}$ & $\begin{array}{l}\text { Length } \\
\text { of the } \\
\text { excretory } \\
\text { surface } \\
\mu\end{array}$ \\
\hline 1 & 252 & 250 & 2 & 68 & 136 & 68000 \\
\hline 2 & 248 & 232 & 2 & 64 & 128 & 59392 \\
\hline 3 & 264 & 258 & 2 & 65 & 130 & 67080 \\
\hline 4 & 238 & 220 & 2 & 63 & 126 & 55440 \\
\hline 5 & 210 & 200 & 2 & 63 & 126 & 50400 \\
\hline 6 & 272 & 265 & 2 & 66 & 132 & 67960 \\
\hline $\begin{array}{l}\text { Ave- } \\
\text { rage }\end{array}$ & 247 & & & & & 61212 \\
\hline
\end{tabular}

The ratio between the length of the excretory surface and the length of the worm: 61212 : $247000:: 0 \cdot 247: 1$.

\section{REMARKS}

Among the polychaetes studied, three, viz., O. erimita, L. medusa and C. insecta, possess nephridia of the mixonephridial type, while in G. embranchiata it is of the protonephromixial type with solenocytes performing the 
function of excretion. Even among the former three forms, in O. eremita and in $L$. medusa the nephridia are simple in structure and small in size compared to that of $C$. insecta which has a nephridium with the nephridial canal long and bent on itself. While in O. ertmita and in G. embranchiata there are a pair to each of the segment except in the anterior and posterior few segments where they are absent, in $L$. medusa there are only three pairs and in $C$. insecta four pairs. Further in the blood supply they receive and in the ratio of the excretory surface to the length of the worm they differ. While in $C$. insecta the nephridia receive the maximum blood supply (22.60 units) with the maximum excretory surface $(1: 0.310)$ in $O$. ermita the blood supply is 15.66 units and the excretory surface (ratio) is $1: 0.247$ and in $L$. medusa they are respectively 6.50 units and $1: 0 \cdot 225$. In G. embranchiata the blood supply is 11.83 units. These differences could perhaps be attributed to their capacities for osmotic regulation as reflected by volume regulation and related to their habitats.

TABLE II

Loimia medusa-Extent of the excretory surface relative to the length of the worm

\begin{tabular}{|c|c|c|c|c|c|c|}
\hline No. & $\begin{array}{l}\text { Length } \\
\text { of the } \\
\text { worm } \\
\mathrm{mm} \text {. }\end{array}$ & $\begin{array}{l}\text { No. of } \\
\text { seg- } \\
\text { ments }\end{array}$ & $\begin{array}{l}\text { Length of } \\
\text { each cell } \\
\text { of the } \\
\text { nephridial } \\
\text { canal } \\
\mu\end{array}$ & $\begin{array}{l}\text { No. of } \\
\text { such } \\
\text { cells }\end{array}$ & $\begin{array}{l}\text { Length } \\
\text { of the } \\
\text { nephridial } \\
\text { canal } \\
\mu\end{array}$ & $\begin{array}{c}\text { Length } \\
\text { of the } \\
\text { excretory } \\
\text { surface } \\
\mu\end{array}$ \\
\hline 1 & 30 & 3 & 8 & 140 & 1120 & 6720 \\
\hline 2 & 32 & 3 & 8 & 142 & 1136 & 6816 \\
\hline 3 & 30 & 3 & 8 & 142 & 1136 & $681 \epsilon$ \\
\hline 4 & 32 & 3 & 8 & 140 & 1120 & 6720 \\
\hline 5 & 30 & 3 & 8 & 140 & 1120 & 6720 \\
\hline 6 & 30 & 3 & 8 & 140 & 1120 & 6720 \\
\hline $\begin{array}{l}\text { Ave- } \\
\text { rage }\end{array}$ & 31 & & & & & 6752 \\
\hline
\end{tabular}

The ratio batween the length of the excretory surface and the length of the worm; $6752: 31000:: 0 \cdot 225: 1$. 
Gross Morphology and Histology of Nephridia in Species of Polychaetes 205

TABLE III

Clymene insecta-Extent of the Excretory surface relative to the length of the worm

\begin{tabular}{ccccccc}
\hline No. & $\begin{array}{l}\text { Length } \\
\text { of the } \\
\text { worm } \\
\text { mm. }\end{array}$ & $\begin{array}{c}\text { No. of } \\
\text { seg- } \\
\text { mists }\end{array}$ & $\begin{array}{l}\text { Length of } \\
\text { each cell } \\
\text { of the } \\
\text { nephridial } \\
\text { canal } \\
\mu\end{array}$ & $\begin{array}{l}\text { No. of } \\
\text { such } \\
\text { cells }\end{array}$ & $\begin{array}{l}\text { Length } \\
\text { of the } \\
\text { nephridial } \\
\text { canal } \\
\mu\end{array}$ & $\begin{array}{l}\text { Length } \\
\text { of the } \\
\text { excretory } \\
\text { surface } \\
\mu\end{array}$ \\
\hline 1 & 25 & 4 & 10 & 111 & 1110 & 8880 \\
2 & 26 & 4 & 10 & 109 & 1090 & 8720 \\
3 & 24 & 4 & 10 & 110 & 1100 & 8800 \\
4 & 25 & 4 & 10 & 109 & 1090 & 8720 \\
5 & 25 & 4 & 10 & 110 & 1100 & 8800 \\
6 & 24 & 4 & 10 & 110 & 1100 & 8800 \\
\hline Average & 25 & & & & & 8780
\end{tabular}

The ratio betwaen the length of the excretory surface and the length of the worm: $8780: 25000:: 0 \cdot 31: 1$.

It was argued in an earlier paper (Krishnamoorthi, 1962) that $C$. insecta showed better powers of volume regulation and consequently greater penetration into the brackish-water zones of Adyar, Madras. From the present investigations have emerged out further evidences to justify the role and importance of nephridia which may have enabled these polychaetes for better adjustments to a changing environment and to account for their distribution. The excretory surface is the maximum in $C$. insecta compared with those of either $O$. erimita or L. medusa, implying that the nephridia are bigger in the former species than in the latter two species. A bigger kidney is certainly an advantage to meet the demands of baling out of water that enters in against an osmotic gradient. It further helps in keeping down the swelling of the animal to the minimum required for the maintenance of a constant internal environment for the smooth functioning of the body tissues and other organ systems. L. medusa and $O$. erlmita, possessing as they do smaller nephridia, have limited powers of regulation. G. embranchiata none at all. Grobben (1881), Schwabe (1933) and Krishnan (1952), examining a number of crusta- 
ceans or polychaetes belonging to same families and genera, have shown that in the stenohaline forms the kidney is the smallest while in freshwater forms it is the biggest, the brackish-water forms ranking in between the two. In the light of the above observations, it appears reasonable to conclude that the relatively large size of the nephridia in $C$. insecta is a definite advantage which has enabled this polychaete a greater penetration into the brackishwater zones and better adaptation for volume regulation calculated to meet the demands of a fluctuating environment. O. erimita, $L$. medus $q$ and G. embranchiata with smaller nephridia are confined to the mouth of the brackish-water regions characterised by stable conditions. From the above it also appears reasonable to suppose that the expenditure of energy would be greater, the higher the grade of adaptation and the greater the excretory effort. The importance of vascularisation of the nephridia viewed in this light needs no emphasis. Of the polychaetes studied the blood supply the nephridia receive in $C$. insecta is the maximum, with $L$. medusa, O. erimita and $G$. embranchiata following in the order mentioned. This is only to be expected since $C$. insecta alone is found in the upper reaches of the brackishwater regions while the other polychaetes have hardly passed beyond the limits of the mouth of the brackish-water regions. Krishnan (1952) has made similar observations in the three Nereids he has studied.

\section{SUMmary}

1. The anatomy and histology of four species of polychaetes, viz., $O$. ertmita, L. medusa, G. embranchiata and $C$. insecta are given.

2. The nephridia in O. eremita, L. medusa and in C. insecta are of the mixonephridial type while in $G$. embranchiata it is of protonephromixial type with simple solenocytes performing the function of excretion. There is a pair to each segment in the former two species excepting in the few anterior and posterior segments. But in $L$. medusa there are only three pairs and in C. insecta four pairs.

3. The blood supply to the nephridia and the extent of the excretory surface to the length of the worm are given. Both in blood supply and in the excretory surface $C$. insecta showed the maximum development. L. medusa, O. erlmita and G. embranchiata showed lesser grades of development in the order mentioned.

4. The differences in the blood supply the nephridia receive and in the extent of the excretory surface to the length of the worm have been argued as due to the different capacities for osmotic regulation as reflected by volume 
regulation. Taking this a measure their distribution in a brackish-water environment has been explained.

\section{ACKNOWLEDGEMENTS}

I am gratefully indebted to Prof. C. P. Gnanamuthu, Director, Zoological Research Laboratory, University of Madras, for the valuable guidance throughout this investigation and to Dr. S. Krishnaswamy, Reader, Zoological Research Laboratory, University of Madras, for the valuable discussions in the preparation of the paper. I am thankful to the University of Madras for the award of a studentship during the tenure of which this piece of work was carried out.

\section{REFERENCES}

Aiyar, R. G.

Beadle, L. C.

Cosmovici, L. C.

Cunningham, J. R.

Ehlers, E.

Ewer, D. W.

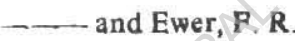

Fage, L.

Fuchs, $\mathbf{K}$.

Goodrich, E, S.
. "On the anatomy of Marphysa gravelyi Southern." Rec. Indian Mus., Calcutta, 1933, 35, 287-323.

"Adaptation to changes of salinity in the Polychaetes. Control of body volume and of body fluid concentration in Nereis diversicolor," Jour, Exp. Biol., 1937, 14, 56-70.

"Glandes, genitales et organes segmentaires des Annelides Polychetes," Arch. Zool. exp. gen., Paris, 1880, 8, 232-372.

"Some points in the anatcmy of Polychaeta," Micr. Sci. Lond. Quart. Jour.. 1887, 28, 239-277.

"Nephridia of Lanice conchilega," Soc. Eding. Soc., Proc., a $887,14,238$.

Die Borstenwurmer nach systematischen und anatomisches Untersuchungen dargestellt. Leipzig, Wilhelm Engelmann, 1864-68, pp. xxx-748.

"The blood system of Sabella and Spirographis," Micr. Sci. Lond. Quar. Jour., 1941, 82, 587.

"Osmotic regulation in Sabella pavonina," Nature, London, 1943, 152, 598-99.

.. "Recherches sur les organes segemnataires des Annelides Polychetes," Sci. Nat. Zool. Paris, Ann, 1906, 3, 261-410.

"Die Topograhie des Blutgefas systems der Chaetopodon,", Jena. Z. Naturw., 1906, 42, 374-484.

.. "On the nephridia of Polychaeta. Part I. On Hesione, Tyrrhena and Nephthys," Micr. Sci. Lond. Quar. Jour., 1897, 40, 185-96.

. " "On the nephridia of Polychaela, Part II. Glycera and Goniada," lbid., 1898, 41, 439-57.

. ' The study of nephridia and genital duct since 1895," Ibid., $1945,86,113-392$. 
208

Grobben, C.

Heasle, C.

Jaquet, $\mathbf{M}$.

Jurgens, Otto

Keferstein, W.

Krishnan, G.

Krishnamoorthi, B.

Marchal, P.

Marshall, E. K. and Smith, H. W.

Meyer, E.

Milne Edwards, $\mathbf{H}$.

Nash, J.

Panikkar, N. K.

Poters, H.

Ranganathan, $\mathbf{v}$.

Schlieper, C. and Herrmann, F.

Schnoider, $\mathbf{G}$.

Schwabe, E.

Westblad, $\mathbf{E}$.

\section{B. KRISHNAMOORTHI}

.. "Die Antennendruse der Crustacean," Arb. Zool. Inst. Univ. Wien., 1881, 3.

.. “Zur Kenntnis der terebellomorphen Polychaetes," Zool. Bidr., Uppsala, 1917, 5, 39-258.

.. "Recherches sur le systeme vasculaire des Anneles," Zool. Stat. Neapel. Mitt., 1886, 6, 297-398.

.. "Die Wechselbeziehungen von blutkeislauf, Atmug und osmoregulation bei Polychaeten Nereis diversicolor O.F. Muller.," Zool. Jahrb. Abt. Allg. Zool., 1935, 55, 1-46.

.. "Untersuchungen uber niedere seethiere," Zeits. Wiss. Zool., Leipzig, 1862, 12, 1-147.

.. "On the nephridia of Nereidae in relation to habitat," Proc. Nat. Inst. Sci., India, 1952, 18, 241-55.

.. "Salinity tolerance and volume regulation in four species of Polychaetes," Proc. Ind. Acad. Sci., 1962, 56, 363-71.

.. "Recherches anatomiques ef physiologiques sur l'appareil excreteur des crestacees decapodes," Arch. Zool. exp. gen. Sci., 1892, 10, 57-275.

"The glomerular development of the vertebrate kidney in relation to habitat," Biol. Bull., 1930, 59, 135-53.

. "Studien uber des Korperbau der Anneliden," Zool. Stat. Neapel. Mitt., 1888, 8, 462-662.

.. "Recherches pour servir a l'histoire de la circulation du sand chez les Annelides," Ann. Sci. Nat., Paris, 1839, 10, 193-221.

The number and size of glomeruli in the kidney of fishes with observations on the morphology of the renal tubules of fishes, Amer. Jour. Anat., 1931, 47, 425-39.

.. "Osmotic regulation in some palaemonid prawns," J. Mar. biol. Ass., U.K., 1941, 25, 317-59.

.. "Uber den Einfluss der Salzgehaltes in Aussen medium auf den Bau und die Funktion der Exkeretionsorgane dekapoden crustaceen. (Nach Untersuchungen an Potamobius fluviatilis und Homarus vulgaris)," Zeitschr. Morpholiokol Tiere, 1935, 30, 355-81.

.. Studies on Polychaetes. M.Sc. Thesis of the University of Madras, 1942 (Unpublished).

"Beziehungen zwischen Bau und Function bei den Exkretionsorganen dekapoden crustaceen," Zool. Jahrb. Abt. Anar. Ontog., 1930, 52, 624-30.

.. "Uber Phagocytose und Exkretion bei den Anneliden," Zeits. Wiss. Zool., Leipzig, 1899, 66, 497-520.

.. "Uber die osmoregulation verschiedener Kresbe (Malacostraceen)," Zeitschr. vergl. Physiol., 1933, 19, 183-235.

.. "Zur Physiologie dur Turbellarien," Lunds Untv. Ansole., 1922, 18, 1-120. 


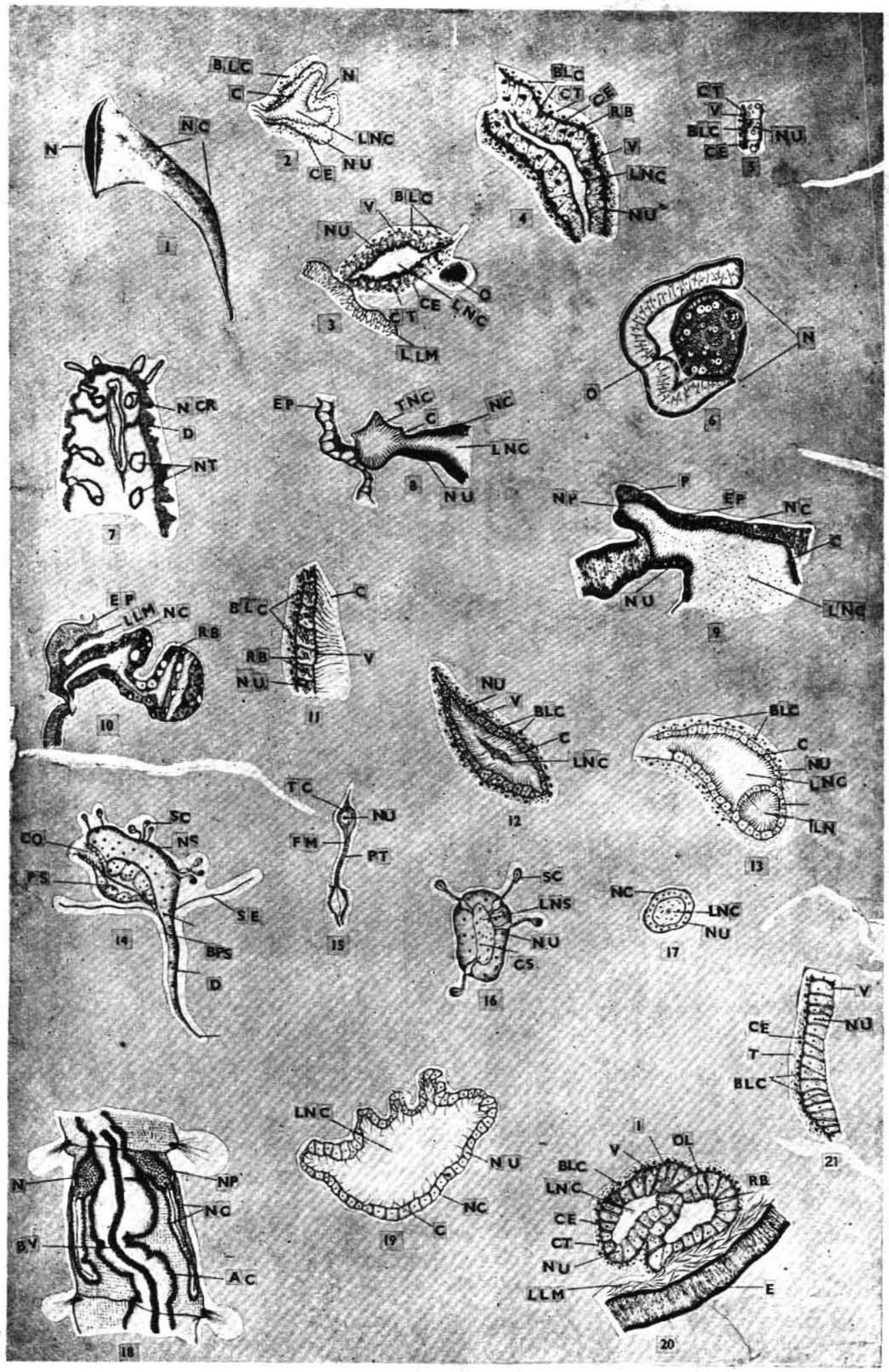




\section{Explanation of Plate $X$ \\ Onuphis ertmita}

FIG. 1. Diagrammatic representation of a single whole nephridium $(x, 400)$.

FIG. 2. Longitudinal section through the nephrostome of the nephridium $(\times 450)$.

Fio, 3. Cross-section through the nephridial canal of the nephridium $(\times 450)$.

Fio, 4. Longitudinal section through the nephridial canal of the nephridium $(\times 400)$.

Fio. 5. Section of a single cell of the nephridial canal $(\times 1,350)$.

Fig. 6. Cross-section through the nephrostome during the maturation period $(\times 400)$.

\section{Loimia medusa}

FiG. 7. Longitudinal section through the anterior 8 segments showing the distribution of the 3 pairs of nephridia $(\times 40)$.

Fro. 8. Lo.ngitudinal section through the terminal part of the nephtidial canal just before opening to the exterior $(\times 200)$.

FIG. 9. Longitudinal section through the terminal part of the nephridial canal of the nephridium to show the opening to the exterior by the nephridiopore on an elevated papillae $(\times 400)$,

Fig. 10. Longitudinal section of a single whole nephridium of the cephalic region $(\times 200)$.

Fig. 11. Longitudinal section through the nephridial canal of the nephridium ( $x, 900)$.

Fic. 12. Cross-section through the nephridial canal $(x 280)$.

Fig. 13. Longitudinal section through the nephridium of the trunk region $(\times 200)$,

\section{Glycera embranchiata}

Fro. 14. Diagrammatic representation to show the composite nature of the nephridium $(x 400)$.

Fro. 15. Longitudinal section through a solenocyte $(x 900)$.

Fro. 16. Cross-section through the nephridial swelling showing the opening of the solenocytes into the lumen of the nephridial swelling $(\times 450)$.

Fig. 17. Cross-section through the nephridial canal $(\Varangle 450)$.

\section{Clymene insecta}

Fio. 18. Longitudinal sections through a segment showing the location of nephridia ( $\times 400$ ).

Fio. 19. Cross-section through the nephrostome of the nephridium $(\times 450)$.

FIG. 20. Longitudinal section of the wall of the nephridial canal $(\times 450)$.

Fio. 21. Cross-section through the two limbs of the nephridium $(\times 200)$.

\section{AbBreviations Used}

AC, Alimentary canal; BC, Blind ending capillaries; BV, Blood vessel; C, Cilia; CE., Cuelomic epithelium; CO, Ciliated organ; CS, Concrements; CT, Connective tissue; D, Diaphragm; EP, Epidermis; EM, Flagellum; IL, Inner limb; LLM, Longitudinal layer of muscles; LN, Lumen of nephrostome; LNC, Lumen of the nephridial canal; LNS, Lumen of the nephridial swelling; N, Nephrostome; NC, Nephridial duct; NP, Nephridiopore; NS, Nephridial swellirg; NT, Nephridia of the trunk region; NU, Nucleus; NCR, Nephridia of the cephalic region; O, Ovum ; OL, Outer limb; P, Papilla; PS, Phagocytal sac; PT, Proximal tube; RB, Refringent bodies; SC, Solonocytes; SE, Septum: TC. Terminal chamber; TNC, Terminal part of the nephridial canal; V. Vacuoles. 